Estuarine, Coastal and Shelf Science

November 2018, Volume 212, Pages 73-79

http://dx.doi.org/10.1016/i.ecss.2018.07.001

http://archimer.ifremer.fr/doc/00448/55969/

(c) 2018 Elsevier Ltd. All rights reserved.

\title{
Seagrass organic matter transfer in Posidonia oceanica macrophytodetritus accumulations
}

\author{
François Remy ${ }^{1}$, Thibaud Mascart ${ }^{1,2}$, Marleen De Troch $^{2}$, Michel Loïc ${ }^{1}$, Gilles Lepoint ${ }^{1,{ }^{*}}$ \\ ${ }^{1}$ FOCUS Centre, Laboratory of Oceanology, University of Liège, Sart Tilman B6c, B-4000, Liège, \\ ${ }^{2}$ Marine Biology Research Group, Ghent University, Krijgslaan 281-S8, B-9000, Gent, Belgium \\ * Corresponding author : Gilles Lepoint, email address : G.Lepoint@uliege.be
} Belgium

\begin{abstract}
:
Seagrass ecosystems are net autotrophic systems which contribute to organic carbon burial in marine sediment. Dead seagrass leaves are often exported outside the seagrass beds and may form accumulations (exported macrophytodetritus accumulations, hereafter EMAs) from littoral zones to deepest canyons. Understanding how seagrass organic matter is channeled in its associated trophic web is necessary to assess the role of the seagrass ecosystem as blue carbon service providers. We used gut content and stable isotope analyses to delineate the Posidonia oceanica EMA food web structure and to determine the importance of detrital material in the diets of macrofauna. Evidence from gut contents and stable isotopes showed that this food web is fuelled mainly by two food sources found in the detritus accumulations: 1) P. oceanica detritus itself and 2) epiphytes and drift macroalgae. Dead leaves of $P$. oceanica enter the diet of dominant species, representing more than $60 \%$ of animal abundance. The food web is structured in five trophic levels with a numerical dominance of detritivore/herbivore species at the first consumer level. Animals act as a vector for seagrass organic matter transfer to upper trophic levels and this "dead seagrass signal" is followed through the entire food web. Seagrass primary production and seagrass organic matter processing by animals are spatially decoupled and this should be taken into account in assessments of seagrass ecosystems as key actors in $\mathrm{C}$ cycles in coastal areas.
\end{abstract}

Keywords: Stable isotopes, Detrital pathway, Mixing models, Trophic level, Invertebrates, Mediterranean Sea, Food web 


\section{INTRODUCTION:}

Accumulations of macrophytodetritus are ubiquitous features of marine ecosystems and are found from littoral zones to deepest canyons, and from high latitudes to tropical zones. These accumulations shelter specific and very abundant animal assemblages (e.g. Crawley and Hyndes, 2007; Gallmetzer et al., 2005; Vetter, 1995), acting as a faunal magnet (Duggins et al., 2016). They are commonly found associated to seagrass meadows. Seagrass meadows are net autotrophic ecosystems and key components of the carbon cycle in coastal areas (Champenois and Borges, 2012). They are now recognised for their importance in the burial of organic carbon in marine sediment and, consequently, in the mitigation of atmospheric $\mathrm{CO}_{2}$ increase (i.e. blue carbon hypothesis) (Duarte and Krause-Jensen, 2017; Ewers Lewis et al., 2017; Lavery et al., 2013). Produced biomass is partly exported outside of the seagrass systems and forms accumulations of macrophytodetritus, mixed with other drift material (macroalgae, living leaves, uprooted rhizomes, dead organisms) (“exported macrophytodetritus accumulations”, hereafter EMAs) (Pergent et al., 1997; Cebrian, 2002; Boudouresque et al., 2016). Therefore, seagrass ecosystems are often a net provider of dead organic material (macrophytodetritus) to unvegetated habitats (Duarte and Krause-Jensen, 2017) and act as trophic subsidies to various ecosystems (Heck et al., 2008).

As for many seagrasses worldwide, the detrital pathway is considered to be a very important route for the incorporation of the organic matter of the Neptune grass Posidonia oceanica (L. Delile, 1813) into coastal food webs, as a large proportion of the foliar primary production can end up in the detrital compartment (Boudouresque et al., 2016; Cebrian, 2002, Mateo and Romero, 1997; Pergent et al., 1997). The P. oceanica dead leaves are often exported out of the meadow to underwater unvegetated places (e.g., bare underwater sand patches). These EMAs are colonised by meiofauna $(38-1000 \mu \mathrm{m})$ (Mascart et al., 2015) and an abundant and diverse vagile macrofaunal (defined here as the fauna retained on $1 \mathrm{~mm}$ sieves 
and smaller than $5 \mathrm{~cm}$ ) community (Como et al., 2008; Dimech et al., 2006; Gallmetzer et al., 2005; Remy, 2016). The EMAs' macrofauna consists of up to 115 species and is dominated by amphipod crustaceans, representing 80 to $97 \%$ of the total abundance (Gallmetzer et al., 2005; Remy, 2016). Because P. oceanica meadows are often impacted by human activities, these particular communities are also potentially disturbed (Calizza et al., 2013).

The heterogeneous nature of the components of EMAs makes them a perfect candidate for a complex food web, with various food sources and distinct trophic preferences among the macrofauna species. Seagrass detritus could thus play a supportive role in these food webs, as was already suggested for certain invertebrates in the P. oceanica meadow (Michel et al., 2015; Vizzini, 2009).

Using a year-long sampling strategy, combining gut content analysis (GCA) and stable isotope analysis (hereafter SIA), we aimed 1. to describe the food web associated to $P$. oceanica macrophytodetritus accumulations and 2. to assess the role of animals living in these accumulations as vectors of seagrass-derived organic matter.

\section{MATERIALS AND METHODS:}

To encompass the temporal and spatial heterogeneity of EMAs, samples were collected on 4 occasions between August 2011 and March 2012 at two shallow (i.e. $10 \mathrm{~m}$ depth) sampling sites near the STARESO oceanographic research station in Calvi Bay $\left(42^{\circ} 35^{\prime} \mathrm{N}, 8^{\circ} 43^{\prime} \mathrm{E}\right.$, Corsica). The sites were approximately $700 \mathrm{~m}$ apart.. Both sampled EMAs were on sandy substrate devoid of vegetation. A precise description of the sampled habitats may be found in Remy, 2016.

The litter and associated macrofauna, defined here as the fauna retained on a $1 \mathrm{~mm}$ sieve and smaller than $5 \mathrm{~cm}$ (Table 2), were manually sampled while scuba diving, using large $30 \mathrm{~L}$ plastic bags. Samples were rinsed with seawater on $1 \mathrm{~cm}$ and $1 \mathrm{~mm}$ sieves to separate the 
animal fraction and the vegetal fraction. The vegetal fraction was retained on $1 \mathrm{~cm}$ mesh, corresponding to potential basal food sources (i.e. dead leaves, living leaves, drift macroalgae, epiphytes).

Suspended particulate organic matter (hereafter SPOM), sampled using Niskin bottles (2.5 L) underwater (1 metre above the EMA, i.e. $9 \mathrm{~m}$ depth), was collected on a GF/F glass fiber filter (pre-combusted at $400^{\circ} \mathrm{C}$ ). Potential food sources were frozen $\left(-20^{\circ} \mathrm{C}\right)$ until further analysis.

The animals in the $1 \mathrm{~mm}$ animal fraction $(\mathrm{n}=566)$ were all identified and put individually in $4 \mathrm{~mL}$ glass vials and frozen $\left(-20^{\circ} \mathrm{C}\right)$ until further analysis. Isotopic and gut content analyses were performed for 19 species, allowing $90 \%$ of individual abundance at each season to be reached and representing all potential trophic levels found in the EMAs.

\section{Gut content analysis}

Gut content analyses were performed using the semi-quantitative technique described by Wilson and Bellwood, 1997, adapted for the very small gut contents of vagile invertebrates. A $4 \mathrm{~cm}^{2}$ grid composed of 100 squares of $4 \mathrm{~mm}^{2}$ was used. Twenty-five squares were randomly chosen and marked out of the 100 and in each square only the dominant food item was taken into account (Wilson and Bellwood, 1997). Dominant food items for this study were visually classified into five categories: (1) dead Posidonia oceanica leaves, (2) living $P$. oceanica leaves, (3) other vegetal material (macroalgae, epiphytes), (4) animal material, and (5) unknown material. Once the 25 squares were examined and the most dominant item noted for each, the relative abundance (\%) of each category was calculated. Organisms presenting an empty gut or less than ten squares containing one of the determined items were excluded from further analysis.

\section{Elemental and stable isotope analysis}


114 After gut removal, each individual was dried $\left(60^{\circ} \mathrm{C}\right)$ for at least $96 \mathrm{~h}$, and ground to form a

115 homogenous powder. Epiphytes that are highly carbonated and crustaceans that may have

116 carbonates in their cuticle were acidified under $37 \% \mathrm{HCl}$ vapour for $15 \mathrm{~h}$ to limit the bias of

117 carbonate content on tissue isotopic composition. After acidification, samples were dried

118 again $\left(60^{\circ} \mathrm{C}\right)$ for $48 \mathrm{~h}$, ground, and put in $6 \mathrm{~mm}^{3}$ tin cups. For animals, individual

119 measurements were performed (see Table 2 for sample numbers). The stable isotope ratios of

120 carbon $\left(\delta^{13} \mathrm{C}\right)$ and nitrogen $\left(\delta^{15} \mathrm{~N}\right)$, and the elemental composition were determined using an

121 isotopic ratio mass spectrometer (Isoprime 100 ${ }^{\mathrm{TM}}$, Isoprime, UK) interfaced in continuous

122 flow with an elemental analyser (vario MICRO cube ${ }^{\mathrm{TM}}$, Elementar). Isotope ratios for $\mathrm{C}$ and

$123 \mathrm{~N}$ were reported conventionally in per mil $(\%)$ using standard delta $(\delta)$ notation relative to

124 their respective international standards, Vienna-Pee Dee Belemnite (V-PDB) and atmospheric $125 \mathrm{~N}_{2}$ :

126

127

$\delta \mathrm{X}=\left(\frac{\mathrm{R}_{\text {sample }}-\mathrm{R}_{\text {standard }}}{\mathrm{R}_{\text {standard }}}\right) \times 10^{3}$

128

129

where $\mathrm{X}={ }^{13} \mathrm{C}$ or ${ }^{15} \mathrm{~N}, \mathrm{R}={ }^{13} \mathrm{C} /{ }^{12} \mathrm{C}$ or ${ }^{15} \mathrm{~N} /{ }^{14} \mathrm{~N}$, and standard $=$ Vienna-Pee Dee Belemnite $(\mathrm{V}$ PDB) and atmospheric $\mathrm{N}_{2}$ for carbon and nitrogen respectively. Pure gases of $\mathrm{CO}_{2}$ and

$\mathrm{N}_{2}$ were used and calibrated against certified reference materials, i.e., sucrose (IAEA-

$\mathrm{C} 6 ; \delta^{13} \mathrm{C}=-10.8 \pm 0.3 \%$ ) and ammonium sulfate (IAEA-N $2 ; \delta^{15} \mathrm{~N}=20.3 \pm 0.3 \%$ ) , obtained from the International Atomic Energy Agency (IAEA, Vienna, Austria). The analytical precision was assessed by procedural blanks, internal replicates (i.e., glycine and in-house crustacean and seagrass reference material) and isotopic certified material (i.e., IAEA-C6 and IAEA-N2). Standard deviations of replicated measurements presented hereafter were $0.4 \%$ for $\mathrm{N}$ elemental composition, $0.7 \%$ for $\mathrm{C}$ elemental composition, $0.1 \%$ for $\delta^{13} \mathrm{C}$, and $0.2 \%$ o 
138 for $\delta^{15} \mathrm{~N}$. Isotopic data from harpacticoid copepods composing the "meiofauna" food source

139 (hereafter, "COP”) are from Mascart et al. (2018).

\section{SIAR modelling}

141 The Bayesian mixing model SIAR (Stable Isotope Analysis in R; Inger et al., 2010; Parnell et 142 al., 2010) was used to give estimations of the contribution of every potential food source to the diet of the invertebrate consumers. The SIAR 4.2.2 package was fitted in $\mathrm{R}$ 3.3.2 ( $\mathrm{R}$ Development Core Team, 2016), using the isotopic composition of each individual, the potential food sources (mean \pm SD), and the trophic enrichment factors (hereafter, TEFs; expressed as mean $\pm \mathrm{SD}$ ). Here TEFs for both isotopic ratios were taken from literature reviews (McCutchan et al., 2003) and published laboratory feeding experiments (Remy et al., 2017; Michel et al., 2015) (food sources, acronyms, and TEFs are detailed in Table 1). The model was run with $10^{6}$ iterations and "burn-in" size set as $10^{5}$. Model outputs were presented as non-metric multidimensional scaling (nm-MDS) representations (+ ANOSIM), or intervals of distribution of probability density functions (see statistics section).

\section{tRophicPosition modelling}

The Bayesian tRophicPosition model package (version 0.5.0.1000; Quezada-

Romegialli et al., 2016) was used to estimate trophic position parameters of all sampled species in R 3.3.2. The model was run using $\delta^{13} \mathrm{C}$ and $\delta^{15} \mathrm{~N}$ values of consumers, basal food sources, and TEFs from Remy et al. (2017) for the living and dead P. oceanica leaves, and from Michel et al. (2015) for epiphytes and SPOM (in red, Table 1). For each species, the model took two baseline items into account that were selected from SIAR model outputs. The two items displaying the highest mode (i.e. contributing the most to each species' diet) in the SIAR output were selected. For predators, the model took into account the baseline items consumed by their prey to remain consistent. The trophic position of these baselines were given the value of $1(\lambda=1)$. For each taxon, two parallel chains were sampled with 10000 
adaptive iterations. Model solutions were presented using credibility intervals of probability density function distributions. When relevant, direct pairwise comparisons of model-

estimated trophic positions were performed. These comparisons were considered meaningful when probability of occurrence exceeded $99 \%$.

\section{Statistical analyses}

An nm-MDS ordination technique and ANOSIM analysis were performed on GCA data and SIAR outputs to distinguish potential temporal patterns and the trophic grouping of the samples. nm-MDS is based on an iterative procedure. In this study, we performed a 2D nmMDS using the corresponding routine of PRIMER v6.1.13 for Windows. We used relative proportion data from gut content examination. The resemblance matrix was built by calculating Bray-Curtis similarity. The number of iterations was set to 99 , and the minimum stress level at 0.01 . Corresponding ANOSIM analysis was performed on relative proportion data using PRIMER v6.1.13 for Windows.

Preliminary ANOVA analyses to test the isotopic separation of sampling sites and potential food sources were performed using R 3.3.2 and all test results were considered significant when $\mathrm{p}$ was $\leq 0.01$. Graphs were built with R 3.3.2 and Primer 6 .

\section{RESULTS}

\section{Gut content analysis}

Of the 566 organisms sampled, $24.39 \%$ had empty guts or did not present enough gut content material for useful observation. Guts from 428 individuals from 14 species were therefore examined, and the main ingested items identified.

From these 14 species, the nm-MDS and 1-way ANOSIM analysis (Figure 1) highlighted five significant (ANOSIM, $\mathrm{p}<0.01$ ) grouping patterns (see Table 2) corresponding to five 
ingestion patterns: 1) "Litter consumers"; 2) “Algal consumers"; 3) "Mixed vegetal consumers"; 4) "Mixed omnivorous consumers"; 5) "Carnivores".

"Litter consumers", ingesting mostly dead leaves of Posidonia oceanica, consisted of the amphipod Gammarus aequicauda (Martynov, 1931) and the isopod Idotea balthica (Pallas, 1772). "Algal consumers", ingesting mostly algal material, consisted of the amphipod Gammarella fucicola (Leach, 1814), the decapods Galathea intermedia (Liljeborg, 1851) and Liocarcinus holsatus (Fabricius, 1798), and the isopod Stenosoma lancifer (Leach, 1814). “Mixed vegetal consumers", ingesting mostly a mix of dead leaves of $P$. oceanica and algal material, consisted of the amphipods Nototropis guttatus (Costa, 1853) and Melita hergensis (Reid, 1939), the decapod Athanas nitescens (Leach, 1813), and the leptostracean Nebalia strausi (Risso, 1826). "Mixed omnivorous consumers", ingesting vegetal but also nonnegligible amounts of animal material, consisted of the decapods Liocarcinus navigator (Herbst, 1794) and Hippolyte leptocerus (Heller, 1863). It must be mentioned that the decapod Palaemon xiphias (Risso, 1816), ingesting almost exclusively animal material, is the only representative of the "carnivores" group of this EMA macrofauna community. Due to very low sample size, Gobius spp. fishes were not included in the ANOSIM analysis but were grouped with $P$. xiphias in the nm-MDS ordination constituting a "group". No significant grouping according to sampling site was found.

\section{Stable isotope analyses}

The $\delta^{15} \mathrm{~N}$ and $\delta^{13} \mathrm{C}$ values of the 19 studied macrofauna species (i.e. the 14 species used in GCA + the 5 species presenting empty guts, for a total of 566 individuals) ranged from -0.9 to $8.5 \%$ and from -23.3 to $-13.0 \%$ respectively (Figure 2). The $\delta^{15} \mathrm{~N}$ and $\delta^{13} \mathrm{C}$ values of the five main basal food sources ranged from 1.0 to 2.2 and from -31.9 to $-13.4 \%$ o respectively (Figure 2). Food sources displayed little or no significant differences in $\delta^{15} \mathrm{~N}$ (1-way ANOVA, $\mathrm{p}>0.01)$ but displayed significant differences in $\delta^{13} \mathrm{C}(1$-way ANOVA, $\mathrm{p}<0.001)$, 
except for the "Algae" and the "Epiphytes" sources (1-way ANOVA, p = 0.322). These two food sources, isotopically indistinguishable from each other, were thus pooled and treated as a single food source in all following analyses. Since no significant difference between the two sampling sites was identified (1-way ANOVA, $\mathrm{p}>0.01$ ), samples from both sites were also pooled for each species in all following analyses.

The SIAR model runs confirm the presence of different dietary preferences (Figure 2, Table 3). The nm-MDS and ANOSIM (1-way ANOSIM, $p<0.001)$ analyses based on the SIAR outputs clearly showed the presence of 3 main significant groups: I, II and III (Figure 2, Table 2). Group I corresponds to primary consumers and is composed of three sub-groups: dead leaf consumers (DL), mixed vegetal consumers (MIX), and Idotea balthica (TR) (Figure 2). Group II is composed of two sub-groups: omnivore consumers (OMNI) and first order carnivorous predators (P1). Group III is composed of only one sub-group, second order carnivorous predators (P2). Overall, each sub-group corresponds to a given dietary preference (Figure 2). In group I, the dead leaf consumers sub-group is composed of organisms assimilating mainly dead leaves of $P$. oceanica. The mixed vegetal consumers sub-group is composed of organisms ingesting mostly a mix of dead leaves of $P$. oceanica and epiphytes/algae. I. balthica is isolated which reflects the fact that it assimilates mostly vegetal items and small amounts of animal tissue (but less than omnivores). Interestingly, SIAR modelling does not retain detritus as an important food source, despite the fact that gut contents were often full of dead leaves. In group II, the omnivore sub-group is composed of organisms consuming a large proportion of animal prey but also a small amount of vegetal material, while first order predators represent pure carnivorous predators consuming only animal prey. Group III was only composed of sub-group P2, juvenile Gobius spp. fishes. This separation was potentially caused by their diet, composed mainly of animals from the first order carnivore sub-group. 
The tRophicPosition model classified the 19 species into four significant "groups" (Figure 3,

Table 2). The first group displayed trophic positions with median values not significantly

different from each other and between 1.2 and 1.8. It is composed of seven species $(G$.

fucicola, G. aequicauda, M. hergensis, N. guttatus, I. balthica, A. corsica, and G. intermedia) which constitute the primary consumers. A second group composed of 8 species (S. lancifer, A. nitescens, H. leptocerus, M. linaresi, L. holsatus, N. strausi, Polychaetes, and B. reticulatum) showed trophic position median values between 2.0 and 2.4, representing the secondary consumers. A third group composed of three species (Palaemon xiphias, Processa edulis, and Liocarcinus navigator) had trophic position median values between 2.6 and 3.0 and thus represents the tertiary consumers. The fourth and last "group" is composed of only one species, the Gobius spp. juveniles, displayed a trophic position median value of 3.9, and represents the quaternary consumers.

\section{DISCUSSION}

Our data highlighted both the important role of epiphytic/algal material but also of dead P. oceanica material to support the food web associated to Posidonia macrophytodetritus accumulations. In terms of numerical abundance (Remy, 2016), the trophic web is dominated by herbivores/detritivores. Herbivores/detritivores represented $50 \%$ of the EMA community (9.4 \pm 23.6 ind. $\mathrm{gDM}^{-1}$; Remy, 2016) with a diet consisting of up to $35 \%$ seagrass detritus. Moreover, the diet of the very abundant G. aequicauda (8.05\% of the EMA community, $2.7 \pm 3.1$ ind. $\mathrm{gDM}^{-1}$; Remy, 2016) contained up to $80 \%$ seagrass detritus. Macrofauna consumption could therefore be a major vector of transmission of seagrass-derived organic matter in EMAs. This implies that this fauna participates not only in the fragmentation and degradation of macrophytodetritus, as revealed by gut contents, but also in the transfer of seagrass organic carbon to upper trophic levels, as revealed by stable isotopes. In terms of 
abundance (Remy, 2016), 60\% of the community assimilates from 35 to $80 \%$ of consumed detrital seagrass material, which is far from negligible in terms of organic matter flux.

The role of detrital seagrasses as a potential food source for marine invertebrates has already been demonstrated in various temperate or tropical seagrass ecosystems (Kharlamenko et al., 2001; Vizzini et al., 2005; Vonk et al., 2008) or EMA systems (Kon et al., 2015; Hyndes and Lavery, 2005). Our study demonstrates that this assimilation, and therefore the seagrass organic matter transfer, is particularly important in $P$. oceanica dead leaf accumulations. This situation seems different from south-western Australia macrophytodetritus accumulations, where Posidonia spp. and Amphibolis spp. seagrass detritus are only weakly transferred in the trophic web (Hyndes and Lavery, 2005). In those EMAs, drift brown macroalgae are also abundant and this material is likely to make a greater contribution to the food web. This implies that EMA composition is likely to influence the associated trophic web.

In our study, the detritus is not the only food sources consumed in important amounts as epiphytes/macroalgae are also very important for community trophic support, like in the $P$. oceanica meadow itself (Michel et al., 2015). The presence of multiple food sources, available in variable amounts, is a key characteristic to maintain a diverse community with diverse diet preferences. The food web found in EMAs contrasts with the P. oceanica meadow itself, where the food web is dominated by small herbivorous species relying on the epiphytic community as food source (Lepoint et al., 2000; Vizzini, 2009). Detritivore amphipods are also present in the $P$. oceanica meadow but are generally not numerically dominant (Michel et al., 2015; Sturaro et al., 2015).

Therefore, detrital pathways occur mainly outside the meadow, in the exported macrophytodetritus accumulations of $P$. oceanica leaves that we have studied here. Seagrass primary production and seagrass organic matter processing by animals are therefore spatially 
decoupled, and this should be taken into account in assessments of seagrass ecosystems as key actors in $\mathrm{C}$ cycles in coastal areas.

According to the tRophicPosition model, this community encompassed 4 consumer levels, with primary consumers/detritivores, secondary omnivore species, first-order predators, and second-order predators. Few species display a more plant-based diet such as the isopod Idotea balthica, in agreement with a previous study focusing on idoteids of $P$. oceanica litter (Sturaro et al., 2010). Nevertheless, this is one species whose gut contents and stable isotopes are not in agreement. Indeed, I. balthica showed high levels of Posidonia detritus in their gut but stable isotope data showed that this detritus did not significantly contribute to the diet, meaning it is not assimilated. More likely, it is the epiphytes and microbes growing on leaves that are assimilated.

Species identified as primary consumers displayed different ingestion and assimilation preferences, but often with a non-negligible consumption of dead $P$. oceanica. For example, the amphipod Gammarus aequicauda showed massive (up to $80 \%$ of the diet) ingestion but also assimilation of dead P. oceanica fragments. The amphipod Gammarella fucicola, which is the most abundant species of this community (around 50\% of individuals; Remy, 2016), and Melita hergensis assimilated large amounts of algae/epiphyte fragments but also assimilated dead P. oceanica leaves. This indicates that, in opposition to G. aequicauda which is specialised in seagrass litter consumption, these two amphipods rely equally on herbivory and on detritus feeding. This is also the case for two other crustaceans: the decapod Galathea intermedia and the isopod Apanthura corsica. They showed intermediate $\delta^{13} \mathrm{C}$ values and present important overlaps with isotopic niches of $G$. fucicola and M. hergensis, indicating the equal consumption and assimilation of algae/epiphyte fragments and fragments of dead P. oceanica leaves. This highlights diet diversity among the detrivorous-herbivorous species, which do not share exactly the same trophic niches. 
The omnivore group, composed of 8 species, was the more diverse but not the most abundant (Remy, 2016). The "typical" species of the group is the decapod Athanas nitescens.

According to SIAR, this species assimilated equal amounts of first order consumers (mainly

Gamarella fucicola as indicated by gut contents) and of harpacticoid copepods, and much less (5\%) algae/epiphytes. Representing $8 \%$ of the total EMA community (Remy, 2016), these omnivores contribute to the transfer of seagrass organic matter via their consumption of detritivores and detritivore/herbivores. They play a crucial vector role in EMAs. This also shows the important role of meiofauna (i.e. animals with a body size between $38 \mu \mathrm{m}$ and $1 \mathrm{~mm}$ ) as an intermediary step in this trophic web (Mascart et al., 2015). In addition, meiofauna may also assimilate seagrass organic matter in these EMAs (Mascart et al., 2018) increasing the potential amount of seagrass organic material transmitted to upper trophic levels.

The third trophic level was composed of 3 large carnivorous decapods: Palaemon xiphias, Processa edulis, and Liocarcinus navigator. These 3 species present quite well-defined niches, except for $P$. edulis that presents an intermediate niche overlapping with both $P$. xiphias and L. navigator. These 3 species shared a similar diet, assimilating a mix of herbivorous/detrivorous consumers, of G. aequicauda, of meiofauna, and, in the case of $P$. xiphias, a non-negligible amount of fish larvae. Even though these predators represent only $0.17 \%$ of the total EMA community (Remy, 2016), their isotopic composition evidences that, through their prey selection, they propagate organic matter-derived dead $P$. oceanica material from the bottom to the top of the food web.

The fourth and last consumer level was not composed of macro-invertebrates but of juvenile fishes of the Gobius genus. This niche corresponds to a diet composed mainly of predator crustaceans from the previous trophic position. Many other fishes are observed in the accumulations and, notably, include small Labridae and Mullidae that are known to feed on 
336

337

338

339

340

341

342

343

344

345

346

347

348

349

350

351

352 small crustaceans. Animals found in the EMAs act as a vector of seagrass organic material to the entire coastal food web, via fishes that feed both in the litter and in other compartments of the system (i.e. macroalgae and seagrass beds, sandy habitats, water column).

The food web described here appears to be based on multiple basal food sources (i.e. seagrass detritus and various pools of epiphytes or microbes). The abundance of detritivores and herbivore/detritivores that are actively consumed by omnivores and predators inside (but also outside) the EMAs make the transfer of seagrass organic material to other compartments of the coastal food web not only possible, but likely efficient. We therefore argue that macrofauna from EMAs can be seen to be major vectors of seagrass-derived organic matter.

\section{ACKNOWLEDGEMENTS}

The authors thank the STARESO field station staff for their assistance during dives and sampling setup. F. Remy acknowledges a F.R.I.A. grant (Belgian National Fund for Research training in Industry and in Agriculture). This study was conducted within the scope of FRSFNRS research project FRFC 2.4511.09. G. Lepoint is a Research Associate of the FRSFNRS. This is publication MARE number xxx. 
353

354

355

356

357

\section{Reference list}

1. Boudouresque, C.F., Pergent, G., Pergent-Martini, C., Ruitton, S., Thibaut, T., Verlaque, M., 2016. The necromass of the Posidonia oceanica seagrass meadow: fate, role, ecosystem services and vulnerability. Hydrobiologia 781, 25-42.

2. Calizza, E., Costantini, M.L., Carlino, P., Bentivoglio, F., Orlandi, L., Rossi, L., 2013. Posidonia oceanica habitat loss and changes in litter-associated biodiversity organization: A stable isotope-based preliminary study. Estuarine, Coastal and Shelf Science 135, 137-145. 3. Cebrian, J., 2002. Variability and control of carbon consumption, export, and accumulation in marine communities. Limnol. Oceanogr. 47, 11-22.

4. Champenois, W., Borges, A.V., 2012. Seasonal and interannual variations of community metabolism rates of a Posidonia oceanica seagrass meadow. Limnol. Oceanogr. $57,347-361$.

5. Como, S., Magni, P., Baroli, M., Casu, D., De Falco, G., Floris, A., 2008.

Comparative analysis of macrofaunal species richness and composition in Posidonia oceanica, Cymodocea nodosa and leaf litter beds. Marine Biology 153, 1087-1101.

6. Crawley KR, Hyndes GA (2007) The role of different types of detached macrophytes in the food and habitat choice of a surf-zone inhabiting amphipod. Marine Biology 151: $1433-1443$.

7. Dimech, M., Borg, J.A., Schembri, P.J., 2006. Motile macroinvertebrate assemblages associated with submerged Posidonia oceanica litter accumulations. Biologia Marina Mediterranea 13, 130-133.

8. Duarte, C.M., Krause-Jensen, D., 2017. Export from seagrass meadows contributes to marine carbon sequestration. Front. Mar. Sci. 4. 
9. Duggins, D.O., Gómez-Buckley, M.C., Buckley, R.M., Lowe, A.T., Galloway, A.W.E., Dethier, M.N., 2016. Islands in the stream: kelp detritus as faunal magnets. Mar. Biol. 163, 1-10.

10. Ewers Lewis, C.J., Carnell, P.E., Sanderman, J., Baldock, J.A., Macreadie, P.I., 2017. Variability and Vulnerability of Coastal 'Blue Carbon' Stocks: A Case Study from Southeast Australia. Ecosystems, 1-17.

11. Gallmetzer, I., Pflugfelder, B., Zekely, J., Ott, J.A., 2005. Macrofauna diversity in Posidonia oceanica detritus: Distribution and diversity of mobile macrofauna in shallow sublittoral accumulations of Posidonia oceanica detritus. Marine Biology 147, 517-523. 12. Heck Jr, K.L., Carruthers, T.J.B., Duarte, C.M., Hughes, A.R., Kendrick, G., Orth, R.J., Williams, S.W., 2008. Trophic transfers from seagrass meadows subsidize diverse marine and terrestrial consumers. ecosystems, 1-13.

13. Hyndes, G.A., Lavery, P.S., 2005. Does transported seagrass provide an important trophic link in unvegetated, nearshore areas? Estuar. Coast. Shelf Sci. 63, 633-643.

14. Inger, R., Jackson, A., Parnell, A., Bearhop, S., 2010. SIAR (Stable Isotope Analysis in R) v4: An Ecologist's Guide.

15. Kharlamenko, V.I., Kiyashko, S.I., Imbs, A.B., Vyshkvartzev, D.I., 2001. Identification of food sources of invertebrates from the seagrass Zostera marina community using carbon and sulfur stable isotope ratio and fatty acid analyses. Marine Ecology-Progress Series 220, 103-117.

16. Kon, K., Tongnunui, P., Kurokura, H., 2015. Do allochthonous inputs represent an important food resource for benthic macrofaunal communities in tropical estuarine mudflats? Food Webs 2, 10-17. 
399

400

401

402

403

404

405

406

407

408

409

410

411

412

413

414

415

416

417

418

419

420

421

422

17. Lavery, P.S., Mateo, M.A., Serrano, O., Rozaimi, M., 2013. Variability in the carbon storage of seagrass habitats and its implications for global estimates of blue carbon ecosystem service. PLoS ONE 8.

18. Layman, C.A., Araujo, M.S., Boucek, R., Hammerschlag-Peyer, C.M., Harrison, E., Jud, Z.R., Matich, P., Rosenblatt, A.E., Vaudo, J.J., Yeager, L.A., Post, D.M., Bearhop, S., 2012. Applying stable isotopes to examine food-web structure: An overview of analytical tools. Biological Reviews 87, 545-562.

19. Lepoint, G., Cox, A.S., Dauby, P., Poulicek, M., Gobert, S., 2006. Food sources of two detritivore amphipods associated with the seagrass Posidonia oceanica leaf litter. Mar. Biol. Res. 2, 355-365.

20. Lepoint, G., Nyssen, F., Gobert, S., Dauby, P., Bouquegneau, J.M., 2000. Relative impact of a seagrass bed and its adjacent epilithic algal community in consumer diets. Marine Biology 136, 513-518.

21. Mascart, T., Lepoint, G., Deschoemaeker, S., Binard, M., Remy, F., De Troch, M., 2015. Seasonal variability of meiofauna, especially harpacticoid copepods, in Posidonia oceanica macrophytodetritus accumulations. J. Sea Res. 95, 149-160.

22. Mascart, T., De Troch, M., Remy, F., Michel, L.N, Lepoint G. , 2018. Seasonal dependence on seagrass detritus and trophic niche partitioning in four copepod ecomorphotypes. Food Webs, in press (accepted 1005 2018)

23. Mateo, M.A., Romero, J., 1997. Detritus dynamics in the seagrass Posidonia oceanica: elements for an ecosystem carbon and nutrient budget. Marine Ecology-Progress Series 151, 43-53.

24. McCutchan, J.H.J., Lewis, W.M.J., Kendall, C., McGrath, C.C., 2003. Variation in trophic shift for stable isotope ratios of carbon, nitrogen, and sulfur. Oikos 102, 378-390. 
25. Michel, L.N., Dauby, P., Gobert, S., Graeve, M., Nyssen, F., Thelen, N., Lepoint, G., 2015. Dominant amphipods of Posidonia oceanica seagrass meadows display considerable trophic diversity. Mar. Ecol. 36, 969-981.

26. Parnell, A.C., Inger, R., Bearhop, S., Jackson, A.L., 2010. Source partitioning using stable isotopes: coping with too much variation. PLoS ONE 5, e9672.

27. Pergent, G., Rico-Raimondino, V., Pergent-Martini, C., 1997. Fate of primary production in Posidonia oceanica meadows of the Mediterranean. Aquatic Botany 59, 307321.

28. Prado, P., Tomas, F., Alcoverro, T., Romero, J., 2007. Extensive direct measurements of Posidonia oceanica defoliation confirm the importance of herbivory in temperate seagrass meadows. Marine Ecology-Progress Series 340, 63-71.

29. Quezada-Romegialli C, Jackson AL, Harrod C (2016) A guide to the use of tRophicPosition. https://cran.r-

project.org/web/packages/tRophicPosition/vignettes/Multiple_species_calculation_of_trophic _position_in_R.html (accessed 14 May 2018)

30. R Core Team, 2016. R: A language and environment for statistical computing. R foundation for Statistical Computing, http://www.R-project.org/, Vienna, Austria 31. Remy, F., 2016. Characterization, dynamics and trophic ecology of macrofauna associated to seagrass macrophytodetritus accumulations (Calvi Bay, Mediterranean Sea), Oceanology. PhD Thesis, University of Liège, Liège, p. 324.

32. Remy, F., Darchambeau, F., Melchior, A., Lepoint, G., 2017. Impact of food type on respiration, fractionation and turnover of carbon and nitrogen stable isotopes in the marine amphipod Gammarus aequicauda (Martynov, 1931). Journal of Experimental Marine Biology and Ecology 486, 358-367. 
33. Sturaro, N., Caut, S., Gobert, S., Bouquegneau, J.-M., Lepoint, G., 2010. Trophic diversity of idoteids (Crustacea, Isopoda) inhabiting the Posidonia oceanica litter. Marine Biology 157, 237-247.

34. Sturaro, N., Lepoint, G., Vermeulen, S., Gobert, S., 2015. Multiscale variability of amphipod assemblages in Posidonia oceanica meadows. Journal of Sea Research 95, 258271.

35. Vetter, E.W., 1995. Detritus-based patches of high secondary production in the nearshore benthos. Marine Ecology Progress Series 120, 251-262.

36. Vizzini, S., 2009. Analysis of the trophic role of Mediterranean seagrasses in marine coastal ecosystems: a review. Botanica Marina 52, 383-393.

37. Vizzini, S., Savona, B., Chi, T.D., Mazzola, A., 2005. Spatial variability of stable carbon and nitrogen isotope ratios in a Mediterranean coastal lagoon. Hydrobiologia 550, 7382.

38. Vonk, J.A., Kneer, D., Stapel, J., Asmus, H., 2008. Shrimp burrow in tropical seagrass meadows: an important sink for litter. Estuar. Coast. Shelf Sci. 79, 79-85. 39. Wilson, S., Bellwood, D.R., 1997. Cryptic dietary components of territorial damselfishes (Pomacentridae, Labroidei). Marine Ecology Progress Series 153, 299-310.

\section{FIGURE LEGENDS}

Figure 1. 2D ordination of samples obtained via non-metric multidimensional scaling (nmMDS), using Bray-Curtis similarities computed on relative proportion data from gut content examination of macrofauna inhabiting Posidonia oceanica dead leaf accumulations. 
471

472

473

474

475

476

477

478

479

480

481

482

483

484

485

486

487

488

489

Figure 2. 2D ordination of samples obtained via non-metric multidimensional scaling (nmMDS) using Bray-Curtis similarities computed on SIAR (Stable Isotope Analysis in R) modelling output (Table 3). Trophic types were determined according to gut content analysis.

DL: seagrass dead leaf consumer; MIX: consumer of both dead leaves and epiphytes; TR: diet transitional between first order consumers and omnivores; OMNI: omnivore; P1: first order carnivore; P2: second order carnivore. Species acronyms: Apanthura corsica (Ac), Athanas nitescens (An), Bittium reticulatum (Br), Galathea intermedia (Gi), Gammarella fucicola (Gf), Gammarus aequicauda (Ga), Gobius spp. (Gspp), Hippolyte leptocerus (Hl), Idotea balthica (Ib), Liocarcinus holsatus (Lh), Liocarcinus navigator (Ln), Macropodia linaresi (Ml), Melita hergensis (Mh), Nebalia strausi (Ns), Nototropis guttatus (Ngu) Polychaeta spp. (Pspp), Processa edulis (Pe), Stenosoma lancifer (S1).

Figure 3. Trophic position calculation using the tRophicPosition model of macrofauna species inhabiting Posidonia oceanica dead leaf accumulations. Dark, median, and light coloured boxes and black dots are respectively the 50\%, 75\%, and 95\% credibility intervals and modes of model solutions' probability density function distributions. Species acronyms may be found in Table 2. 
Table 1. Trophic enrichment factors (TEF) (i.e. net difference between the isotopic composition of this food source and the isotopic composition of consumer tissues) used to calculate the contribution of each aggregated food source to the macrofaunal diet.

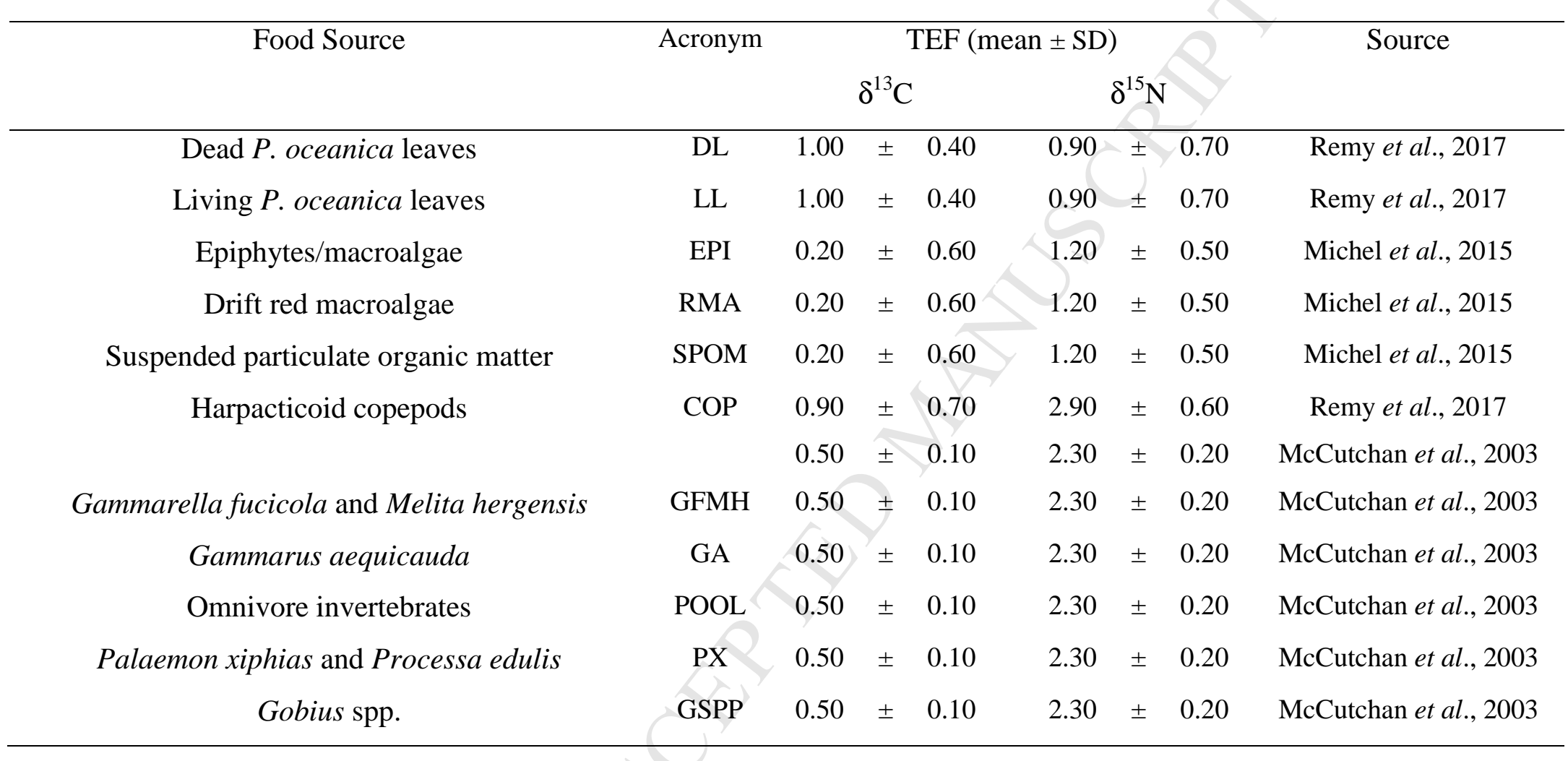


493 Table 2. $\delta^{13} \mathrm{C}$ and $\delta^{15} \mathrm{~N}$ values (mean $\pm \mathrm{SD}$ ), major feeding type and/or food item, and trophic positions of macrofauna inhabiting Posidonia

494 oceanica dead leaf accumulations, using gut content analysis and stable isotope data.

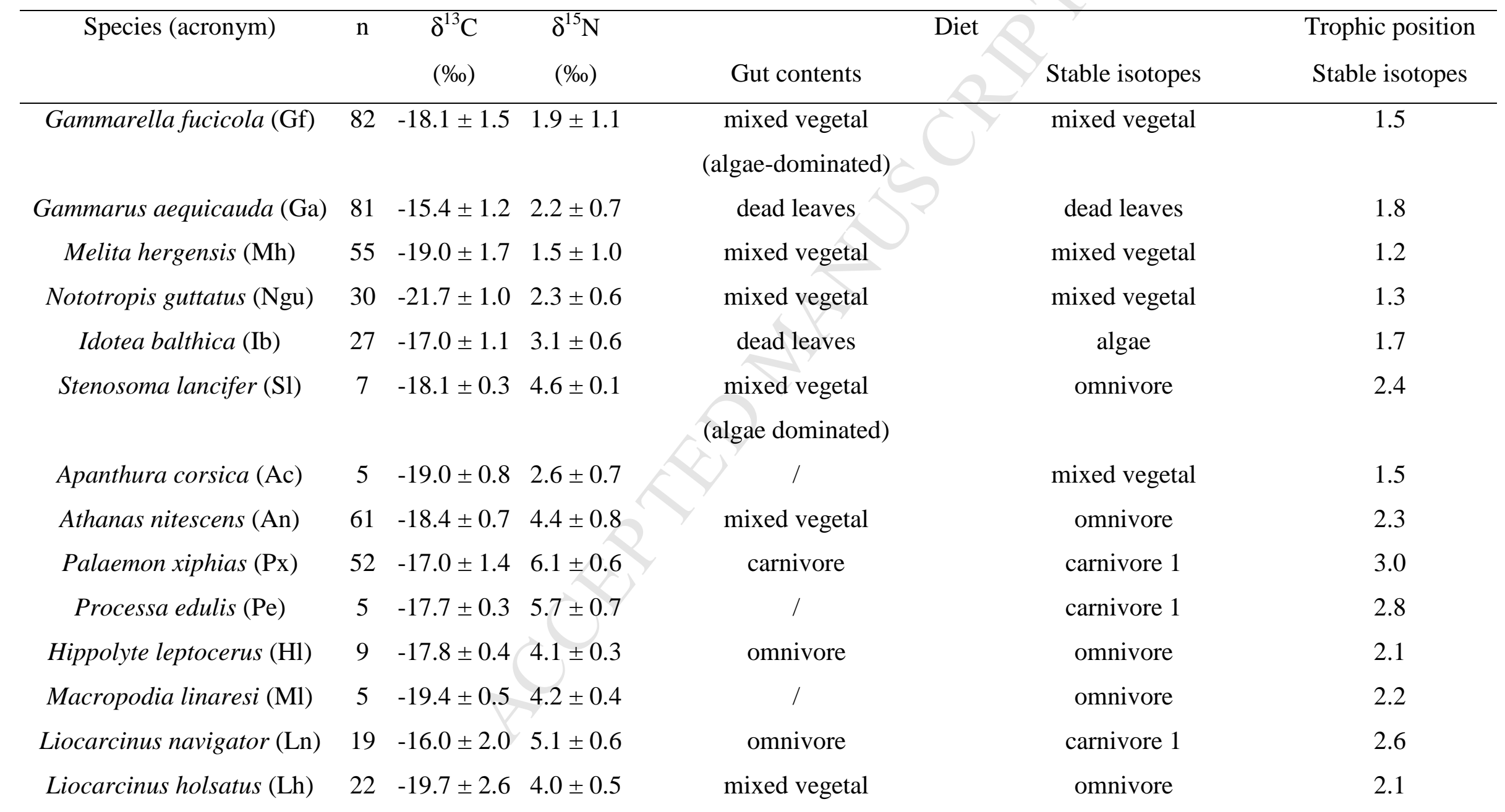


(algae-dominated)

Galathea intermedia (Gi) $\quad 13 \quad-18.4 \pm 0.5 \quad 2.5 \pm 1.3 \quad$ mixed vegetal

mixed vegetal

(algae-dominated)

Nebalia strausi (Ns) $\quad 31 \quad-17.5 \pm 0.6 \quad 3.9 \pm 0.7$

mixed vegetal

omnivore

2.0

Polychaeta spp. (Pspp) $\quad 38 \quad-18.2 \pm 0.6 \quad 3.9 \pm 0.8$

Bittium reticulatum $(\mathrm{Br}) \quad 9 \quad-13.8 \pm 0.3 \quad 3.7 \pm 0.6$

omnivore

2.1

Gobius spp. (Gspp)

$9 \quad-17.9 \pm 1.6 \quad 8.1 \pm 0.3$

dead leaves

2.0

carnivore 2

3.9

495 
496

497

498 499

\begin{tabular}{|c|c|c|c|c|c|c|c|c|c|}
\hline \multirow[t]{2}{*}{ Species names } & \multirow[t]{2}{*}{ Food sources } & \multicolumn{3}{|c|}{ Food source contributions } & \multirow[t]{2}{*}{ Species names } & \multirow[t]{2}{*}{ Food sources } & \multicolumn{3}{|c|}{ Food source contributions } \\
\hline & & $\mathrm{CI}_{95}$ inf & Mode & $\mathrm{CI}_{95} \sup$ & & & $\mathrm{CI}_{95} \inf$ & Mode & $\mathrm{CI}_{95} \sup$ \\
\hline \multirow[t]{5}{*}{ Gamarella fucicola } & Dead leaves & 4.7 & 33.5 & 58.1 & Hippolyte leptocerus & Dead leaves & 0 & 0.9 & 10.3 \\
\hline & Epi & 5.6 & 41.8 & 84.0 & & Epi & 4.1 & 20.8 & 36.2 \\
\hline & SPOM & 0.1 & 10.5 & 31.1 & & GFMH & 7.0 & 29.1 & 48.8 \\
\hline & RMA & 0 & 1.4 & 15.9 & & GA & 0 & 8.3 & 23.8 \\
\hline & Cop & 0 & 0.4 & 3.9 & & Cop & 18.0 & 35.9 & 54.8 \\
\hline \multirow[t]{5}{*}{ Gammarus aequicauda } & Dead leaves & 47.8 & 60.3 & 80.6 & Iacropodia linaresi & Dead leaves & 0 & 1.5 & 21.3 \\
\hline & Epi & 1.6 & 48.7 & 33.6 & & Epi & 0 & 13.0 & 31.4 \\
\hline & SPOM & 0 & 14.2 & 1.3 & & GFMH & 0.8 & 27.9 & 48.2 \\
\hline & RMA & 0 & 7.8 & 0.9 & & GA & 0 & 23.3 & 38.7 \\
\hline & Cop & 0 & 2.9 & 0.2 & & Cop & 7.0 & 31.5 & 56.7 \\
\hline \multirow[t]{5}{*}{ Melita hergensis } & Dead leaves & 5.1 & 34.1 & 55.03 & Liocarcinus navigator & Living leaves & 0 & 0.9 & 13.8 \\
\hline & Epi & 1.6 & 34.3 & 72.3 & & Dead leaves & 0 & 0.9 & 13.6 \\
\hline & SPOM & 1.2 & 23.6 & 39.2 & & Epi & 0 & 0.8 & 11.4 \\
\hline & RMA & 0 & 1.8 & 20.9 & & GFMH & 0 & 2.1 & 28.5 \\
\hline & Cop & 0 & 0.5 & 5.3 & & GA & 15.2 & 43.3 & 68.9 \\
\hline \multirow[t]{2}{*}{ Nottotropis guttatus } & Dead leaves & 0.5 & 23.4 & 37.5 & & Cop & 7.5 & 34.0 & 60.9 \\
\hline & Epi & 1.0 & 29.0 & 52.7 & Liocarcinus holsatus & Dead leaves & 0 & 1.0 & 13.6 \\
\hline
\end{tabular}




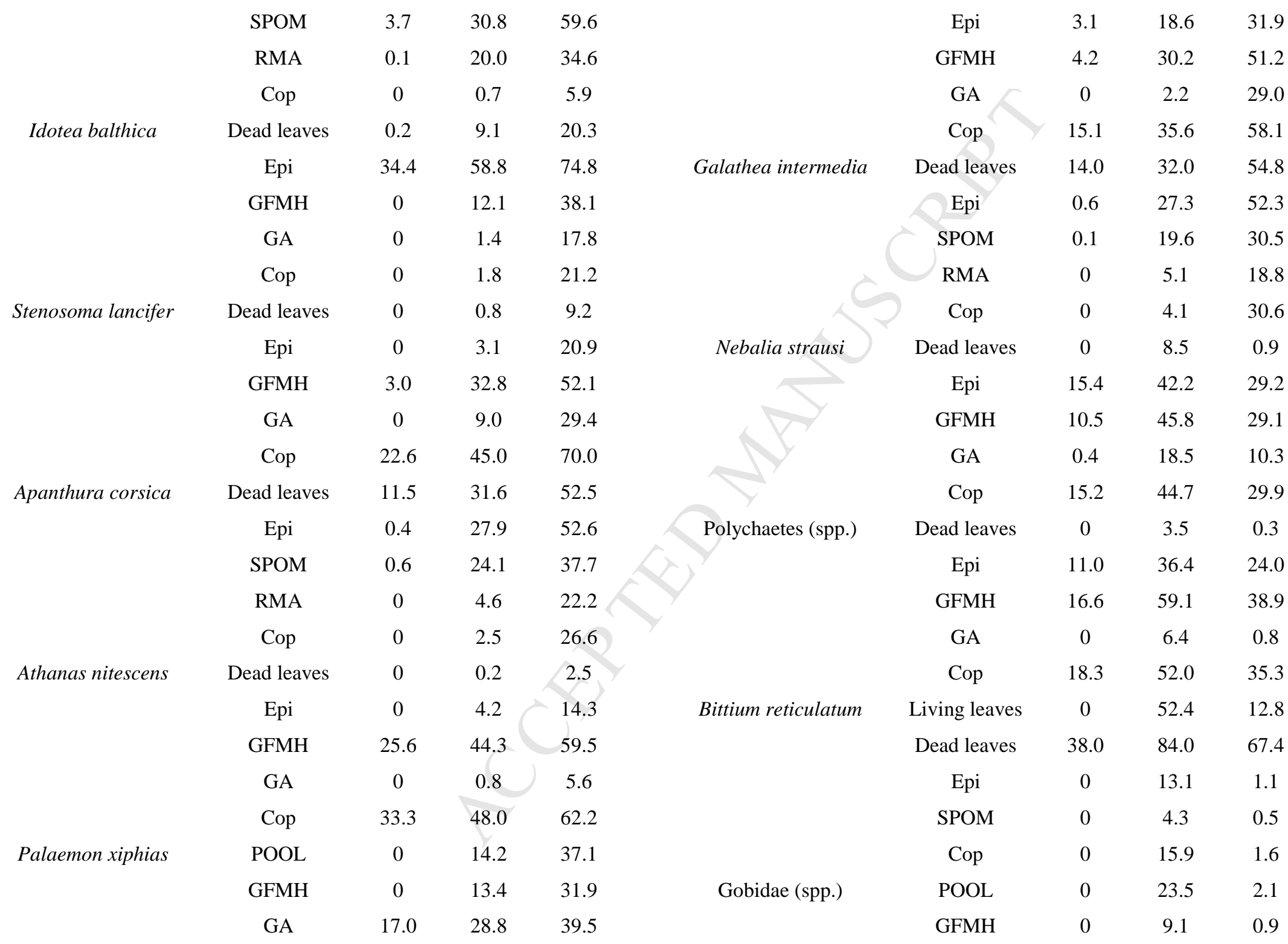




\begin{tabular}{ccccccccc} 
& GSPP & 14.5 & 23.1 & 30.2 & GA & 0 & 8.5 & 0.7 \\
Processa edulis & Cop & 0 & 16.8 & 33.2 & PX & 65.5 & 92.6 & 81.6 \\
& POOL & 0.9 & 24.0 & 42.9 & Cop & 0 & 11.3 & 1.0 \\
& GFMH & 3.2 & 25.4 & 41.2 & & \\
& GA & 1.1 & 18.1 & 30.3 & & \\
& GSPP & 2.1 & 13.2 & 25.0 & & \\
& Cop & 1.3 & 23.7 & 40.1 & & \\
\hline
\end{tabular}

500 


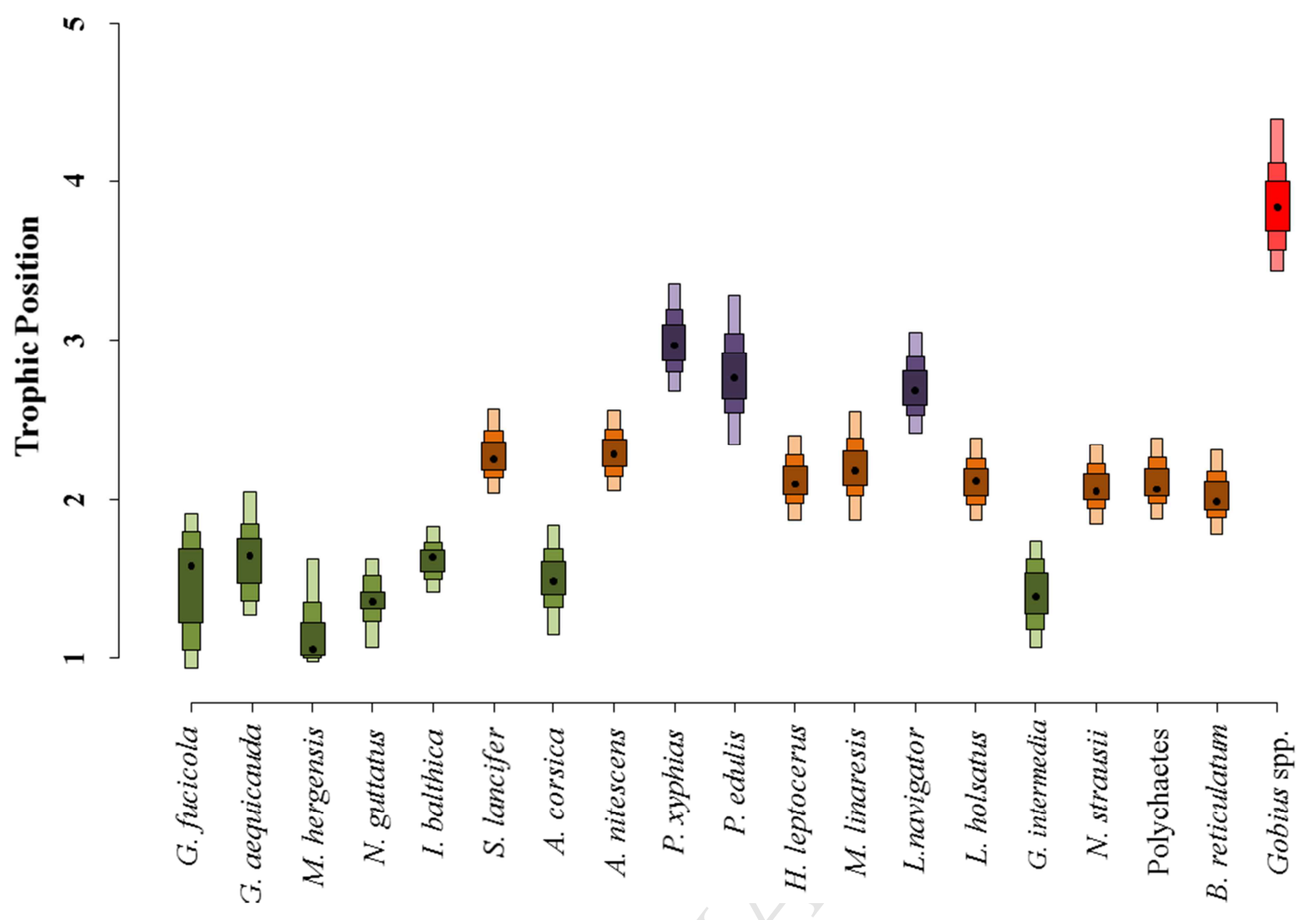




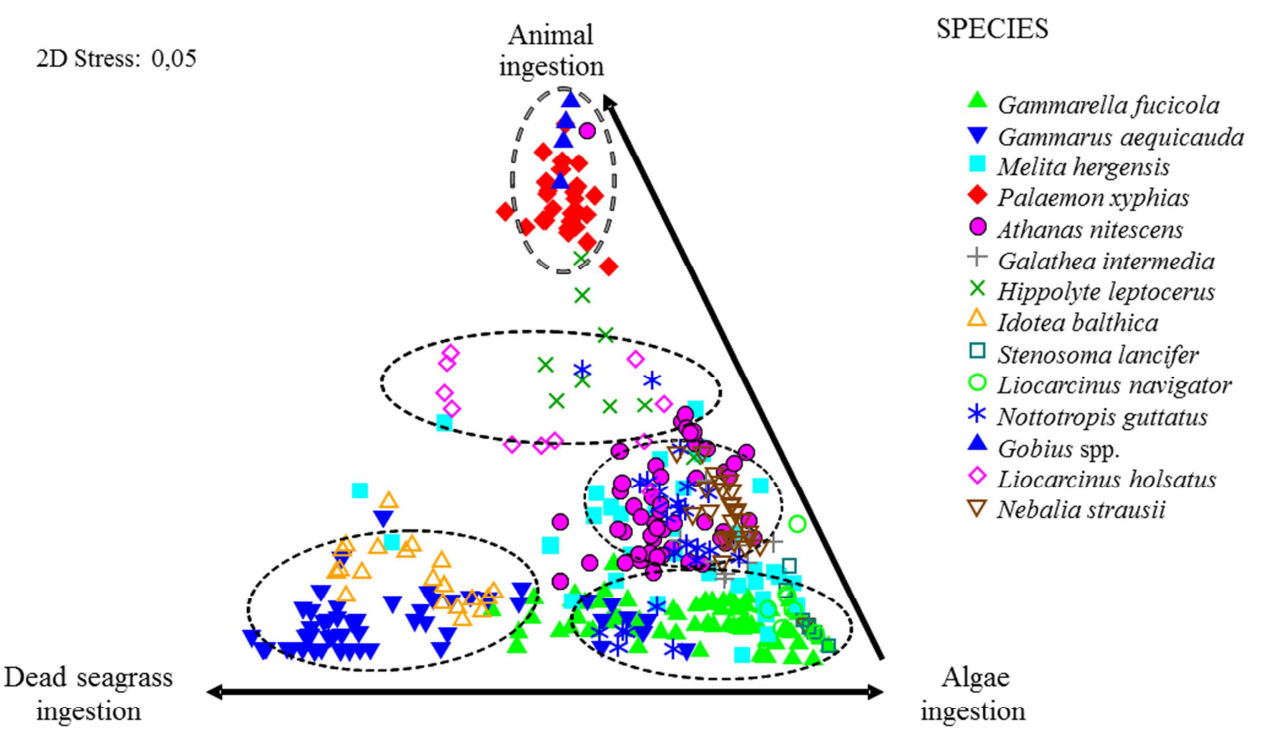




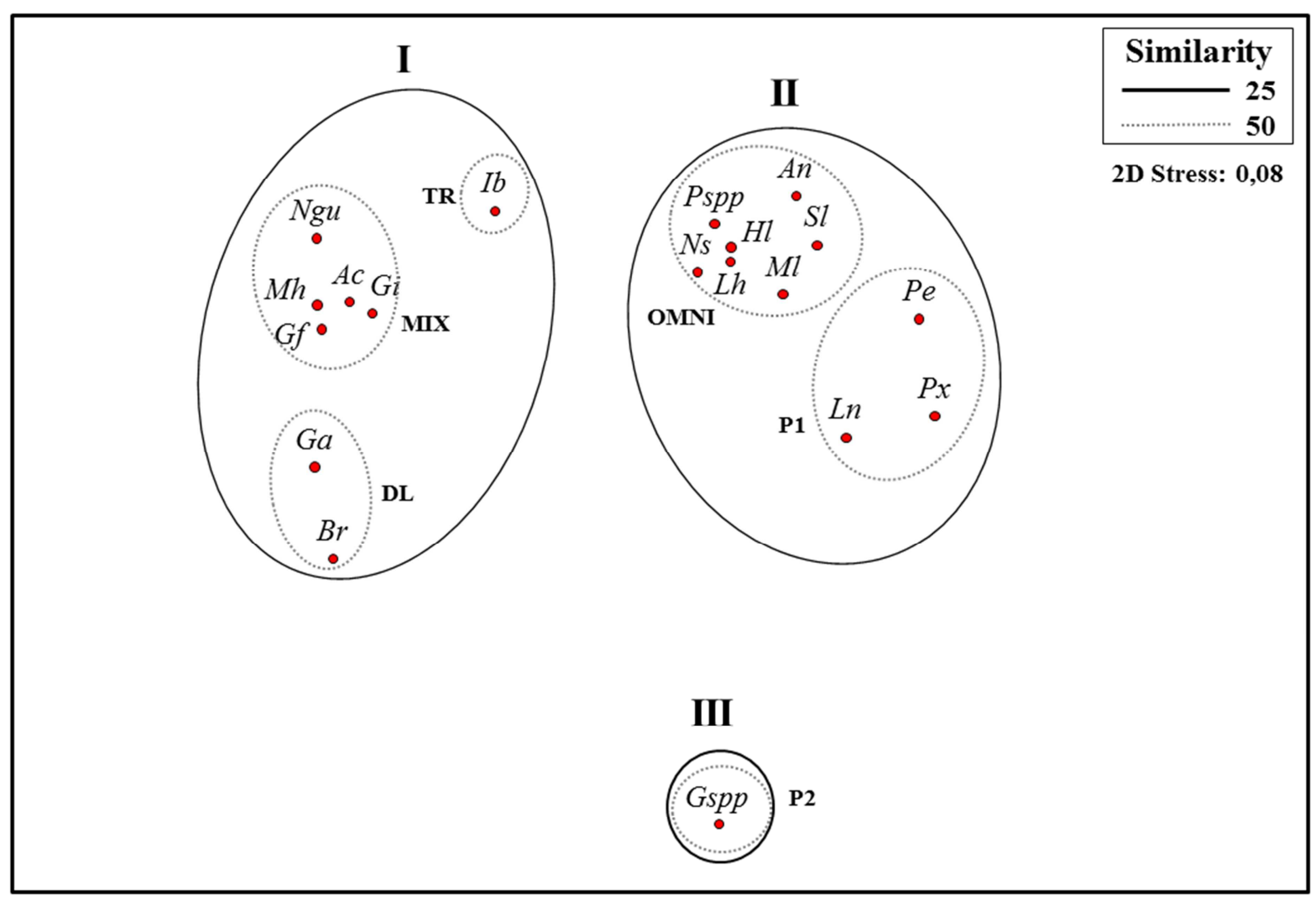

